\section{Characterizing transport of natural and anthropogenic constituents in a long-term agricultural watershed in the northeastern United States}

\author{
T.L. Veith, H.E. Preisendanz, and K.R. Elkin
}

\begin{abstract}
As recent technologies enable water samples to be collected at increasingly shorter time intervals, water quality data can more fully capture the range of conditions a stream experiences over time. Various metrics can be employed with the large, high-temporal resolution (i.e., subdaily) data sets to gain insights into the hydroclimatic and biogeochemical processes affecting chemical fate and transport. These insights can be helpful in understanding the extent to which anthropogenic activities have impacted the natural response of some constituents, such as nutrients and salts, in managed landscapes. Here, nearly four years $(12,544$ samples from 2015 to 2019) of water quality data for 12 constituents of interest were collected using three sampling strategies: (1) low-frequency sampling three times per week, (2) high-temporal resolution flow-paced sampling to capture stormflow, and (3) high-frequency time-paced sampling with a time interval of four hours. Seasonal trends were investigated to understand concentration variability over time, and concentration-discharge $(C-Q)$ relationships were developed to categorize the transport dynamics of each constituent. Lorenz curves and Gini coefficients were employed to quantify the temporal inequality of the constituent loads discharged at the watershed outlet and understand the extents to which the transport behaviors of geogenic constituents and those affected by anthropogenic activities differed Overall, the results suggested that nearly all of the geogenic constituents, plus nitrate-nitrogen $\left(\mathrm{NO}_{3}-\mathrm{N}\right)$ and sulfate $\left(\mathrm{SO}_{4}-\mathrm{S}\right)$, exhibited chemostatic dynamics with loads overwhelmingly controlled by flow variability, whereas aluminum $(\mathrm{Al})$, iron $(\mathrm{Fe})$, nitrite- $\mathrm{N}\left(\mathrm{NO}_{2}-\mathrm{N}\right)$, and orthophosphate $\left(\mathrm{PO}_{4}-\mathrm{P}\right)$ exhibited episodic transport dynamics that were likely controlled by limited source availability. Since the transport of $\mathrm{NO}_{3}-\mathrm{N}$ was found to be similar to the transport of common geogenic constituents for the region, this suggests that decades of agricultural activities in the watershed have led to the emergence of legacy $\mathrm{N}$ sources, while the episodic dynamics observed for $\mathrm{PO}_{4}-\mathrm{P}$ suggest that best management practices appear to have prevented the emergence of $\mathrm{P}$ legacy sources.
\end{abstract}

Key words: agriculture—CEAP—concentration-discharge—geogenic constituents—legacy nutrients — surface water

The temporal resolutions over which surface water samples are collected can profoundly affect our understanding of how water quality changes over time, uncover the benefits or limitations of best management practices, and provide insight into whether or not legacy nutrient sources are present. Traditional water sampling strategies have been based on routine grab sampling methodologies that involve a person physically collecting water samples at these sampling strategies can provide for a robust analysis of how baseflow water quality changes over time in response to changes in land use or land management.

In an effort to improve our understanding of the environmental benefits of past agricultural conservation practices and to maximize the contributions of current and future conservation practices, the USDA Natural Resources Conservation Service (NRCS) Conservation Effects Assessment Project (CEAP; USDA NRCS 2019) has promoted ongoing watershed monitoring and modeling efforts in CEAP watersheds and the more recently established research scenarios of the Long-term Agroecosystem Research Network (LTAR; USDA ARS 2019). In conjunction with these efforts, temporal sampling strategies have been evaluated for practicality and effectiveness at the plot $(2.2$ $\left.\times 10^{-4} \mathrm{ha}\right)$ and small watershed scale $(<25$ $\mathrm{km}^{2}$ ) (King and Harmel 2004; King et al. 2005). The most effective sampling strategies would capture the full range of a vast array of constituent concentrations and ensure both baseflow and stormflow dynamics are appropriately captured.

The temporal resolution at which samples are collected is of critical importance in development of accurate concentration-discharge (C-Q) relationships, which provide valuable insights into the extent to which hydrologic and biogeochemical variability are driving the transport dynamics of a constituent of interest (Basu et al. 2011; Thompson et al. 2011) and to calculate loads with minimal errors (Harmel et al. 2003). If a constituent of interest increases during surface runoff events, and high flow events are not adequately captured, then the true ranges of concentrations and loads are underestimated, with annual load underestimation being as high as 40\% (Haggard et al. 2003; Ullrich and Volk 2010). However, storm-event sampling

Tamie L. Veith (corresponding author) is an agricultural engineer at the USDA Agricultural Research Service (ARS) Pasture Systems and Watershed Management Research Unit, University Park, Pennsylvania. Heather E. Preisendanz is an associate professor of Agriculture and Biological Engineering and the director of the Center of Excellence for Contaminants of Emerging Concern at The Pennsylvania State University, University Park, Pennsylvania. Kyle R. Elkin is a research chemist at the USDA ARS Pasture Systems and Watershed Management Research Unit, University Park, Pennsylvania. 
can generate data sets that bias high concentrations during periods of high flow, causing load overestimation (Robertson and Roerish 1999). In order to reduce bias in load calculations, concentration data that represent both stormflow and baseflow conditions in appropriate proportions are needed. Flowpaced sampling as opposed to time-paced can provide such a data set, but only if the volume of flow used to trigger the collection of a water quality sample adequately captures chemograph changes that may happen during a storm event (Harmel et al. 2003; Gall et al.2010). Samples need to capture the rising and recession limbs of hydrographs, as well as the hydrograph peak, in order to prevent missing elevated concentrations for solutes that exhibit accretion dynamics and low concentrations for solutes that exhibit dilution dynamics.

Recent advances in data analysis techniques seek to leverage water quality data to construct $C$-Q relationships that can facilitate characterization of the transport dynamics of chemicals of interest (Godsey et al. 2009; Thompson et al. 2011; Gall et al. 2015; Musolff et al. 2015). One method utilizes the power function to relate concentration $(C)$ and discharge $(Q), C=a Q^{b}$, where $a$ and $b$ are empirical constants (Haygarth et al. 2004; Vogel et al. 2005). Constituents originating from small, hydrologically unavailable or disconnected sources within a catchment typically exhibit high temporal variabilities in concentration when they reach the stream (Thompson et al. 2011), while catchments with large, hydrologically available or connected sources generate relatively constant biogeochemical responses, with low variability in concentrations observed at the catchment scale (Godsey et al. 2009). The former scenario is referred to as an "episodic" response, with high concentrations occurring during short periods of time (i.e., storm events), such that these short periods of time are disproportionately more important to overall transport behavior than other periods of time (i.e., baseflow conditions). The latter scenario produces $C-Q$ relationships with $b \sim 0$, such that the response is categorized as "chemostatic."

Chemostatic conditions are common for geogenic constituents, such as magnesium $(\mathrm{Mg})$ and calcium $(\mathrm{Ca})$, which weather from large geologic sources within the landscape (Godsey et al. 2009). However, the addition of anthropogenic sources of solutes that have low natural sources in the landscape, such as fertilizer and manure inputs of nitrogen $(\mathrm{N})$ and phosphorus $(\mathrm{P})$, can create large legacy sources that overwhelm the natural variability, causing chemostatic responses to emerge (Basu et al. 2010, 2011; Thompson et al. 2011). When transport dynamics are chemostatic, hydrologic variability is the dominant control on solute export, while biogeochemical variability (i.e., source availability) is the dominant control for solutes exhibiting episodic behavior (Thompson et al. 2011). These responses are neither solute-specific nor catchment-specific, as catchments that exhibit chemostatic responses for some solutes may exhibit episodic responses for others and vice versa (Johnson et al. 1969; Mańczak and Florczyk 1971; Duffy and Cusumano 1998; Godsey et al. 2009; Basu et al. 2010; Thompson et al. 2011; Halliday et al. 2012). Additionally, these responses may be controlled by natural processes or result from long-term changes in intensive management practices.

Here, we leverage nearly four years of water quality data $(12,544$ total water samples across three sampling regimes) at a headwater watershed in northeastern United States to explore the effects of the temporal resolution at which the samples were collected on the development of $C-Q$ relationships and annual load calculations. Twelve constituents of interest are included in the analysis: chloride $(\mathrm{Cl})$, nitrate- $\mathrm{N}\left(\mathrm{NO}_{3}-\mathrm{N}\right)$, nitrite- $\mathrm{N}$ $\left(\mathrm{NO}_{2}-\mathrm{N}\right)$, orthophosphate-P $\left(\mathrm{PO}_{4}-\mathrm{P}\right)$, sulfate $\left(\mathrm{SO}_{4}-\mathrm{S}\right)$, aluminum $(\mathrm{Al}), \mathrm{Ca}$, iron $(\mathrm{Fe})$, potassium (K), Mg, sodium ( $\mathrm{Na}$ ), and silica (Si). These constituents represent a range of geogenic constituents expected to be driven largely by natural weathering processes and constituents whose natural biogeochemical cycles have been impacted by agricultural and other anthropogenic activities occurring in the watershed (e.g., fertilizer application and road salt). C-Q relationships were developed for each constituent using data collected with three sampling strategies: (1) three times per week; (2) high-temporal resolution flow-paced sampling at a stage change of $2.54 \mathrm{~cm}$ to capture stormflow; and (3) time-paced sampling with a time interval of four hours. These intervals were selected based on previous data collected from the compound weir at the site prior to the commencement of this experiment. Two years of rainfall and stream depth changes were used to calculate the average stream depth change $(30.5 \mathrm{~cm})$ during storm events. The threshold of $2.54 \mathrm{~cm}$ for triggering samples was chosen to best capture the rising and recession limbs of the hydrograph. For larger storm events, a four-hour interval was found to be frequent enough to capture the remainder of the hydrograph recession limb.

Results of the analyses presented here demonstrate the extent to which current management practices adopted within the watershed have been successful at improving or protecting water quality at the watershed scale. Additionally, this study highlights important implications for understanding flow conditions under which best management practices must be effective in order to meet water quality restoration goals for impaired water bodies, and provides insights into the extent to which nutrient legacy sources will need to be reduced before water quality improvements can be realized.

\section{Materials and Methods}

Study Site. This research was conducted in a USDA Agricultural Research Service (ARS) experimental watershed known as WE-38. WE-38 is a $7.3 \mathrm{~km}^{2}$ subcatchment within the Mahantango Creek $\left(420 \mathrm{~km}^{2}\right)$ watershed located in the Ridge and Valley Province of east-central Pennsylvania (figure 1). The climate in the watershed is temperate, with average annual precipitation of $1,080 \mathrm{~mm}$ and mean temperature of $\sim 10^{\circ} \mathrm{C}$ (Bryant et al. 2011). Underlying geology is dominantly comprised of sandstone at higher elevations and shale and siltstone in valley bottoms (Gburek and Folmar 1999). The higher elevation soils are well drained, while the lower lands are typically poorly drained with perched water tables and frequently generate saturation excess runoff.

Within WE-38, about 39\% of the land area is mature forest; $3 \%$ is permanent pasture; $2 \%$ is developed; and $55 \%$ is in silviculture, commercial vegetable production, or, most predominately, forage crop rotations. Agriculture is the dominant land use in the shale and siltstone portions of the watershed, while forests are dominant in the higher elevation sandstone regions (Schnabel et al. 1993). Field sizes average 1.1 ha, with a range of 0.01 ha to 14 ha, and have not varied substantially in size in the past 15 years (Veith et al. 2015). On the steep hillslopes, fields are narrow, farmed on-the-contour, and are in alternating rotations of corn (Zea mays L.) or soy (Glyzine max [L.] Merr.) with hay or alfalfa (Medicago sativa L.) so that 


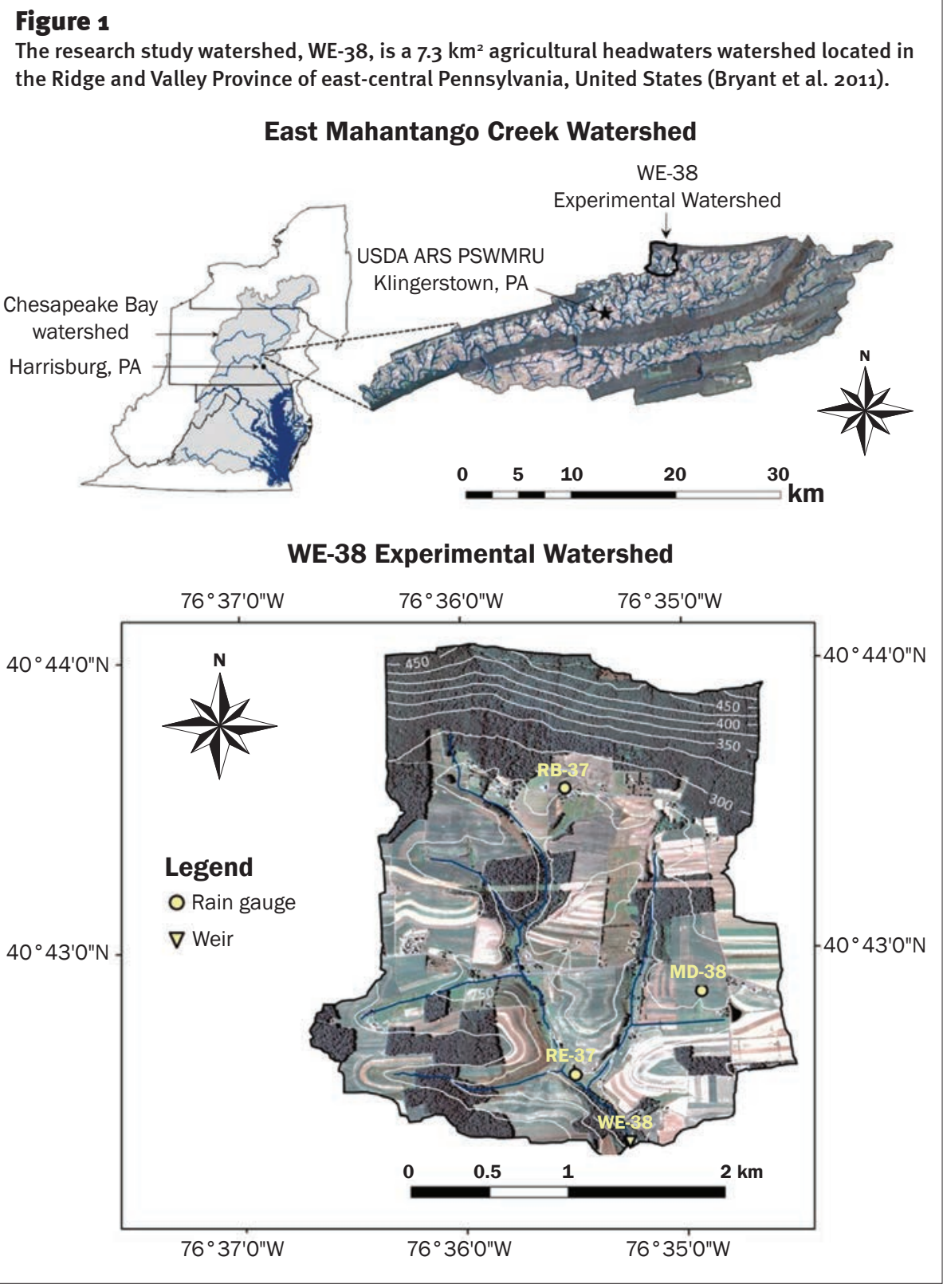

the hillslopes are essentially strip cropped. Primary agricultural activities in the watershed and surrounding regions include nonintensive beef, dairy, and swine farming plus supportive forage cropping. More details about specific agricultural practices are provided in Liu et al. (2017). Manure accounts for about $20 \%$ of total $\mathrm{N}$ and $30 \%$ of total $\mathrm{P}$ applications in the watershed, with about $50 \%$ of it being applied in the late fall and winter. The effects of the timing of manure application on water quality in the watershed are evaluated and discussed by Liu et al. (2017). Remaining agronomic requirements are met through chemical fertilizer applications, primarily applied in the spring.
Hydrologic Data Collection. Water level in the stream has been measured at five-minute intervals at the main outlet of the watershed (Buda et al. 2011) since 1968. The gauging station contains a compound weir, such that low flows are measured through a V-notch $\left(90^{\circ}\right)$ sharp-crested weir and high flows are measured through a $5: 1$ broad crested weir The stage heights were monitored in separate stilling wells using a float and shaft encoder (Campbell Scientific CS410) connected to a datalogger (Campbell Scientific CR1000X, Logan, Utah).

Water Quality Sampling and Analysis. During the study period, water quality data were collected at the watershed outlet using three strategies: (1) low-frequency sampling three times per week, (2) high-temporal resolution flow-paced sampling to capture stormflow, and (3) high-frequency timepaced sampling with a time interval of four hours. The samples collected using the first strategy were collected $130 \mathrm{~m}$ upstream of the weir manually by field technicians. Samples for the second sampling strategy were triggered by the datalogger when water level in the stream, as measured by the shaft encoders, changed by $2.54 \mathrm{~cm}$. After the $2.54 \mathrm{~cm}$ rise in water level, samples were triggered every half hour until the storm receded. Samples for the third sampling strategy were triggered by the datalogger based on time (every four hours). The samples triggered by the datalogger were collected by an automated sampler (Hach AS950, Loveland, Colorado). All samples were collected in $500 \mathrm{~mL}$ high density polyethylene (HDPE) bottles and were handled as described in Church et al. (2011).

Upon collection from the field, each $500 \mathrm{~mL}$ sample was split into two portions and immediately transported on ice from Klingerstown, Pennsylvania, to University Park, Pennsylvania. One portion of each sample was left unfiltered and analyzed by inductively coupled plasma (ICP) for $\mathrm{Al}, \mathrm{Ca}, \mathrm{Fe}, \mathrm{K}, \mathrm{Mg}, \mathrm{Na}$, and $\mathrm{Si}$. The remainder of each sample was passed through a $0.45 \mu \mathrm{m}$ filter and analyzed for $\mathrm{Cl}, \mathrm{NO}_{3}-\mathrm{N}$, $\mathrm{NO}_{2}-\mathrm{N}, \mathrm{PO}_{4}-\mathrm{P}$, and $\mathrm{SO}_{4}{ }^{2}-\mathrm{S}$ by ion chromatography (ICS-5000; Thermo-Fisher Dionex, Sunnyvale, California).

The method limit of detection (LOD) and quantification (LOQ) for each constituent of interest are $0.01 \mathrm{mg} \mathrm{L}^{-1}$ and $0.1 \mathrm{mg} \mathrm{L}^{-1}$, respectively. The LOD was determined by a signal to noise ratio of 3 and the LOQ was determined by a signal to noise ratio of 10 . Lab blanks were included in each instrument run to ensure no carryover between samples, and check standards were run every 40 samples. Further, one sample per instrument run was run three times to ensure the instrument was performing accurately. No gap filling was conducted, as the percentage of missing or erroneous data was small $(<1 \%)$ for the flow data and constituents of interest.

Development and Interpretation of Concentration-Discharge Relationships. $C-Q$ relationships using the empirical relationship $C=a Q^{b}$ (Haygarth et al. 2004; Vogel et al. 2005) were developed for each of the constituents of interest for each of the sampling strategies. When plotted on a log-log scale, the slope of the trendline, $\log (C)=b$ 
$\times \log (Q)+a$, can be used to determine the value of $b$ for each relationship. The $b$ value can then be used to characterize the $C-Q$ pattern as accretion $(b>0)$, dilution $(b<0)$, or chemostatic $(b \sim 0)$. These patterns were used to provide insight into the transport dynamics exhibited by the constituents of interest throughout the study period.

It is possible for constituents with significant variability in their concentrations to show no relationship with flow (i.e., $b \sim 0$ ). Therefore, to further understand the role of hydrologic variability versus concentration variability in the transport of each of the constituents of interest, a ratio of the coefficient of variation of concentration $(\mathrm{CVC})$ versus the coefficient of variation of discharge $\left(\mathrm{CV}_{\mathrm{Q}}\right)$ was employed following Thompson et al. (2011). The higher the ratio of $\mathrm{CV}_{\mathrm{C}} /$ $\mathrm{CV}_{\mathrm{Q}}$, the more concentration variability drives loads and transport from a watershed. However, when concentration variability is low, the variability in flow is much larger and the $\mathrm{CV}_{\mathrm{C}} / \mathrm{CV}_{\mathrm{Q}}$, ratio is low. After analyzing solute and discharge data from nine experimental watersheds (31 subwatersheds) across the United States, Thompson et al. (2011) suggested that constituents having $\mathrm{CV}_{\mathrm{C}}$ / CVQ values of 0.30 or less indicated chemostatic behavior, with hydrologic variability controlling constituent export dynamics. Constituents with $\mathrm{CV}_{\mathrm{C}} / \mathrm{CV}_{\mathrm{Q}}$ values greater than 0.30 exhibit episodic transport, such that both flow variability and concentration variability play important roles in determining transport to the watershed outlet. The higher the value of $\mathrm{CV}_{\mathrm{C}} / \mathrm{CV}_{\mathrm{Q}}$ for a constituent, the more important that variations in concentration are to its export dynamics (Thompson et al. 2011; Gall et al. 2013; Musolff et al. 2015).

Flux and Load Calculations. For each sampling strategy, fluxes were calculated by multiplying constituent concentrations and the flowrate observed at the time the sample was collected. When concentrations were below the LOD, loads were considered to be zero. When concentrations were between the LOD and LOQ, concentrations equal to half the LOQ were used to calculate the flux. Fluxes were assumed to be constant for the time between sampling events and were utilized to calculate loads for each sampling strategy. Given the relatively high frequency of data collected, even for the lowest temporal resolution sampling strategy (every few days over a four-year period), the longest time between sampling periods was five days. Exceptions included approximately a month toward the end of 2017 when the weir was being cleaned and repaired and another month from the end of December of 2018 to early February of 2019 when the US government was shut down and no field or laboratory work could be conducted. Data were not extrapolated during these time periods and were excluded from the load calculations.

Temporal Inequality Calculations for Discharge and Loads. Lorenz inequality curves and their corresponding Gini coefficients were developed for loads calculated from the time-paced samples following methodology described by Jawtiz and Mitchell (2011) and Gall et al. (2013). While commonly used in economics to quantify wealth inequality, the method is gaining attraction in hydrologic and water quality research to quantify the temporal inequality of loads and to understand the relative importance of low flow and high flow events to the observed loads (Jawitz and Mitchell 2011; Gall et al. 2013; Masaki et al. 2014; Musolff et al. 2015; Opalinski et al. 2016). Lorenz inequality curves are generated by sorting the load data in ascending order and plotting the cumulative fraction of load observed over the study period versus the cumulative fraction of time over which the loads were exported.

The Gini coefficient is a formal measure of inequality that varies from 0 to 1 and is calculated as the ratio of the area between the line of equality and the Lorenz curve to the area under the line of equality (Jawitz and Mitchell 2011; Gall et al. 2013). A value of 0 indicates that all moments in time contribute equally to discharge and load (i.e., discharge and loads are constant). At the other extreme, a Gini coefficient value of 1 indicates perfect inequality, such that all of the discharge and solute loads are exported during one instant in time. The Gini coefficient values for constituent loads $\left(G_{L}\right)$ can be compared to the values for discharge $\left(G_{Q}\right)$. A ratio of $G_{L} / G_{Q} \sim 1$ indicates that discharge is the dominant driver of the observed loads, while $G_{L} / G_{Q}>1$ indicates that load inequality is much greater than discharge inequality. The value of $G_{L} / G_{Q}$ is approximately 1 when $b \sim 0$ and $\mathrm{CV}_{\mathrm{C}} / \mathrm{CV}_{\mathrm{Q}}$ is low (i.e., $\sim 0.30$ or less). Constituents with $b>0$ typically have high $\mathrm{CV}_{\mathrm{C}} / \mathrm{CV}_{\mathrm{Q}}$ ratios $(>0.30)$ and $G_{L} / G_{Q}>1$, whereas constituents with $b<0$ typically have $G_{L} / G_{Q}<1$ (Gall et al. 2013). A visual method of inter- preting the results of the $b$ and $\mathrm{CV}_{\mathrm{C}} / \mathrm{CV}_{\mathrm{Q}}$ results is provided by Musolff et al. (2015). Therefore, each of these metrics can be used to characterize the transport dynamics of constituents of interest in a catchment.

\section{Results and Discussion}

Each of the sampling strategies produced a different number of samples during the study period, with the three times per week strategy producing $\sim 500$ samples, the stormflow sampling producing nearly 5,000 samples, and the time-paced sampling (every four hours) producing more than 7,000 samples (table 1). The extent to which the ranges of flow were sampled with each sampling strategy varied widely (figure 2a). The flow duration curve for time-paced samples, which were collected every four hours, very closely matched the flow duration curve for the complete five-minute flow data over the study period (figure $2 \mathrm{~b}$ ). In contrast, flow duration curves for the samples collected three times per week underrepresented high flow events and overrepresented baseflow events. Conversely, the flow duration curves for stormflow sampling overrepresented the high flow events and underrepresented low flow events.

Summary of Water Quality Data. The percentage of samples with concentrations above the LOQ were generally above 95\%, with $\mathrm{NO}_{2}-\mathrm{N}, \mathrm{PO}_{4}-\mathrm{P}, \mathrm{Al}$, and $\mathrm{Fe}$ below the LOQ for the vast majority (>90\%) of samples collected (table 1). The different sampling strategies tended to censor the data at approximately the same levels, with the percentage of samples from each sampling strategy below the LOD and LOQ remaining fairly consistent. Overall, the time-paced sampling strategy captured higher concentrations for the nutrients $\left(\mathrm{N}\right.$ species, $\mathrm{PO}_{4}-\mathrm{P}$, $\mathrm{SO}_{4}-\mathrm{S}$, and $\mathrm{K}$ ) and $\mathrm{Cl}$, while the streamflow samples captured higher concentrations for all other constituents.

The concentrations observed during the study period exceeded the recommended levels for cattle drinking water use $(20 \mathrm{mg}$ $\mathrm{N} \mathrm{L}^{-1}$ for $\mathrm{NO}_{3}+\mathrm{NO}_{2}-\mathrm{N}$ and $0.3 \mathrm{mg} \mathrm{L}^{-1}$ for Fe; Swistock 2015) in less than $1 \%$ of the samples collected. Calcium, $\mathrm{Cl}, \mathrm{Mg}, \mathrm{Na}$, and $\mathrm{SO}_{4}-\mathrm{S}$ were below the recommended levels $\left(500 \mathrm{mg} \mathrm{L}^{-1}, 250 \mathrm{mg} \mathrm{L}^{-1}, 500 \mathrm{mg}\right.$ $\mathrm{L}^{-1}, 20 \mathrm{mg} \mathrm{L}^{-1}$, and $334 \mathrm{mg} \mathrm{S} \mathrm{L}^{-1}$ respectively; Swistock 2015) for the entire study period. Nitrate plus $\mathrm{NO}_{2}-\mathrm{N}$ exceeded the primary drinking water standard $(10 \mathrm{mg} \mathrm{N}$ 
$\mathrm{L}^{-1}$; USEPA 2019) in approximately $20 \%$ of the samples collected.

Seasonal trends were examined by combining data from all three sampling strategies into three-month subsets over the periods of record (figure 3 ). The highest concentrations for $\mathrm{Al}, \mathrm{Cl}, \mathrm{Fe}, \mathrm{Na}$, and $\mathrm{Si}$ were observed in the winter months, while the highest $\mathrm{NO}_{3}-\mathrm{N}$ concentrations were observed in the spring months; $\mathrm{K}, \mathrm{NO}_{2}-\mathrm{N}, \mathrm{PO}_{4}-\mathrm{P}$, and $\mathrm{SO}_{4}-\mathrm{S}$ were highest in the summer, and $\mathrm{Ca}$ was highest in the fall. Application of road salts in the winter months likely contributed to elevated concentrations of $\mathrm{Cl}$ from January through March relative to concentrations observed in the summer and fall. Elevated levels of $\mathrm{NO}_{3}-\mathrm{N}$ observed during the spring and fall reflect the timing of manure and fertilizer applications to agricultural fields within the watershed. Although $\mathrm{PO}_{4}-\mathrm{P}$ was generally below $1 \mathrm{mg} \mathrm{L}^{-1}$, concentrations were greater than $3 \mathrm{mg} \mathrm{P} \mathrm{L}^{-1}$ for a several-week period at the end of June through the beginning of July of 2018 during a window of time that was identified by the National Climatic Data Center as being the wettest on record (NOAA 2019). Overall, concentrations for most of the constituents of interest were fairly consistent over time with similar averages across all seasons (figure 3), suggesting that their transport through the watershed likely depends heavily on hydrologic responses of this watershed, which are largely driven by variable source area saturation excess runoff (Buda et al. 2013).

Concentration-Discharge Relationships. C-Q relationships illustrate how well the different sampling strategies captured concentration ranges and variability of each constituent (figure 4), with the time-paced sampling strategy best representing the full range of observed flows while the three times per week strategy missed the highest flow events and the stormflow sampling missed low flow conditions. Slopes of the C-Q relationships generated by the timepaced sampling strategy were calculated to characterize the relationship between concentration and flow as a dilution pattern $(b<$ $0)$, an accretion pattern $(b>0)$, or independent of the flowrate $(b \sim 0)$ (table 2$)$.

Nearly all of the constituents of geologic origin ( $\mathrm{Ca}, \mathrm{Cl}, \mathrm{K}, \mathrm{Mg}, \mathrm{Na}$, and $\mathrm{Si}$ ) exhibited weak dilution patterns or relatively chemostatic responses ( $b$ values between -0.09 and 0.06; table 2). These results are consistent with earlier monitoring studies conducted at

\section{Table 1}

Data summary for constituents of interest collected for each sampling strategy.

\begin{tabular}{|c|c|c|c|}
\hline & $3 \times$ weekly & Stormflow & Time-paced (4 h) \\
\hline Constituent & $n=472$ & $n=4,968$ & $n=7,104$ \\
\hline \multirow[t]{3}{*}{ Chloride $\left(\mathrm{mg} \mathrm{L}^{-1}\right)$} & 7.15 to 34.74 & 3.05 to 51.05 & 0.16 to 104.10 \\
\hline & $460>$ LOD & $4,878>$ LOD & $6,779>$ LOD \\
\hline & $460>$ LOQ & $4,877>$ LOQ & $6,777>$ LOQ \\
\hline \multirow[t]{3}{*}{ Nitrate-N (mg L-1) } & 0.73 to 11.53 & 0.27 to 21.97 & 0.12 to 22.46 \\
\hline & $472>$ LOD & $4,882>$ LOD & $6,787>$ LOD \\
\hline & $472>$ LOQ & 4,882 > LOQ & $6,781>$ LOQ \\
\hline \multirow[t]{3}{*}{ Nitrite-N (mg L-1) } & - & 0.10 to 1.36 & 0.10 to 1.65 \\
\hline & $0>$ LOD & $2,250>$ LOD & $2,771>$ LOD \\
\hline & $0>$ LOQ & $454>$ LOQ & $577>$ LOQ \\
\hline \multirow[t]{3}{*}{ Orthophosphate-P (mg L-1) } & - & 0.10 to 3.40 & 0.10 to 4.82 \\
\hline & $4>$ LOD & $856>$ LOD & $706>$ LOD \\
\hline & $0>\mathrm{LOQ}$ & $104>$ LOQ & $72>$ LOQ \\
\hline \multirow[t]{4}{*}{ Sulfate-S (mg L-1) } & 1.75 to 5.93 & 0.1 to 7.91 & 0.64 to 8.97 \\
\hline & $460>$ LOD & 4,884 > LOD & $6,757>$ LOD \\
\hline & $460>$ LOQ & 4,881 > LOQ & $6,753>$ LOQ \\
\hline & & $n=3,590$ & $n=4,637$ \\
\hline \multirow[t]{3}{*}{ Aluminum (mg L-1) } & & 0.10 to 3.80 & 0.11 to 1.04 \\
\hline & & $540>$ LOD & $92>$ LOD \\
\hline & & $288>$ LOQ & $37>$ LOQ \\
\hline \multirow[t]{3}{*}{ Calcium (mg L-1) } & & 5.74 to 23.10 & 8.15 to 22.12 \\
\hline & & 3,588 > LOD & 4,635 > LOD \\
\hline & & 3,588 > LOQ & 4,635 > LOQ \\
\hline \multirow[t]{3}{*}{ Iron $\left(\mathrm{mg} \mathrm{L}^{-1}\right)$} & & 0.105 to 2.19 & 0.11 to 0.74 \\
\hline & & $1,062>$ LOD & $490>$ LOD \\
\hline & & 391 > LOQ & $69>$ LOQ \\
\hline \multirow[t]{3}{*}{ Potassium (mg L-1) } & & 0.17 to 7.46 & 0.18 to 50.60 \\
\hline & & $3,590>$ LOD & $4,637>$ LOD \\
\hline & & 3,590 > LOQ & $4,637>$ LOQ \\
\hline \multirow[t]{3}{*}{ Magnesium (mg L-1) } & & 1.62 to 7.66 & 2.69 to 8.06 \\
\hline & & $3,588>$ LOD & $4,635>$ LOD \\
\hline & & $3,588>$ LOQ & $4,635>$ LOQ \\
\hline \multirow[t]{3}{*}{ Sodium (mg L-1) } & & 0.54 to 21.60 & 0.55 to 18.90 \\
\hline & & 3,589 > LOD & $4,637>$ LOD \\
\hline & & $3,589>$ LOQ & $4,636>$ LOQ \\
\hline \multirow[t]{3}{*}{ Silica $\left(\mathrm{mg} \mathrm{L}^{-1}\right)$} & & 1.18 to 6.49 & 0.27 to 5.52 \\
\hline & & $3,588>$ LOD & $4,636>$ LOD \\
\hline & & 3,588 > LOQ & 4,636 > LOQ \\
\hline
\end{tabular}

the study site, which found $\mathrm{Ca}, \mathrm{Cl}, \mathrm{Mg}$, and $\mathrm{Na}$ to be among the dominant ions present in samples collected (Gburek and Folmar 1999) at the watershed outlet. Given that the dominant parent materials at the study site include sandstone, siltstone, and shale (Schnabel et al. 1993), the high occurrence of these constituents is expected. Additionally, nutrients such as $\mathrm{SO}_{4}-\mathrm{S}, \mathrm{NO}_{3}-\mathrm{N}$, and $\mathrm{K}$ exhibited concentrations that remained relatively constant over the full range of flowrates observed at the site, likely due to anthropogenic fertilizer inputs to the landscape or atmospheric deposition that can overwhelm the natural variability associated with background levels of these constituents (Elkin et al. 2016; Basu et al. 2010).

In contrast, $\mathrm{Al}$ and $\mathrm{Fe}$ were typically below the LOD during low flow conditions, such that the $C-Q$ relationships appear to generate chemostatic $(b \sim 0)$ patterns despite the low number of samples that were pres- 


\section{Figure 2}

(a) Hydrograph for period of study (April of 2015 to February of 2019) using discharge measurements made at a five-minute interval; and (b) flow duration curves (FDCs) for flowrates observed during the study period at five-minute intervals and corresponding to samples collected during each of the three sampling strategies: (1) three times per week, (2) stormflow sampling, and (3) time-paced sampling (every four hours). Note that discharge data were not collected in fall of 2017 (September to November) due to maintenance conducted on the weir.

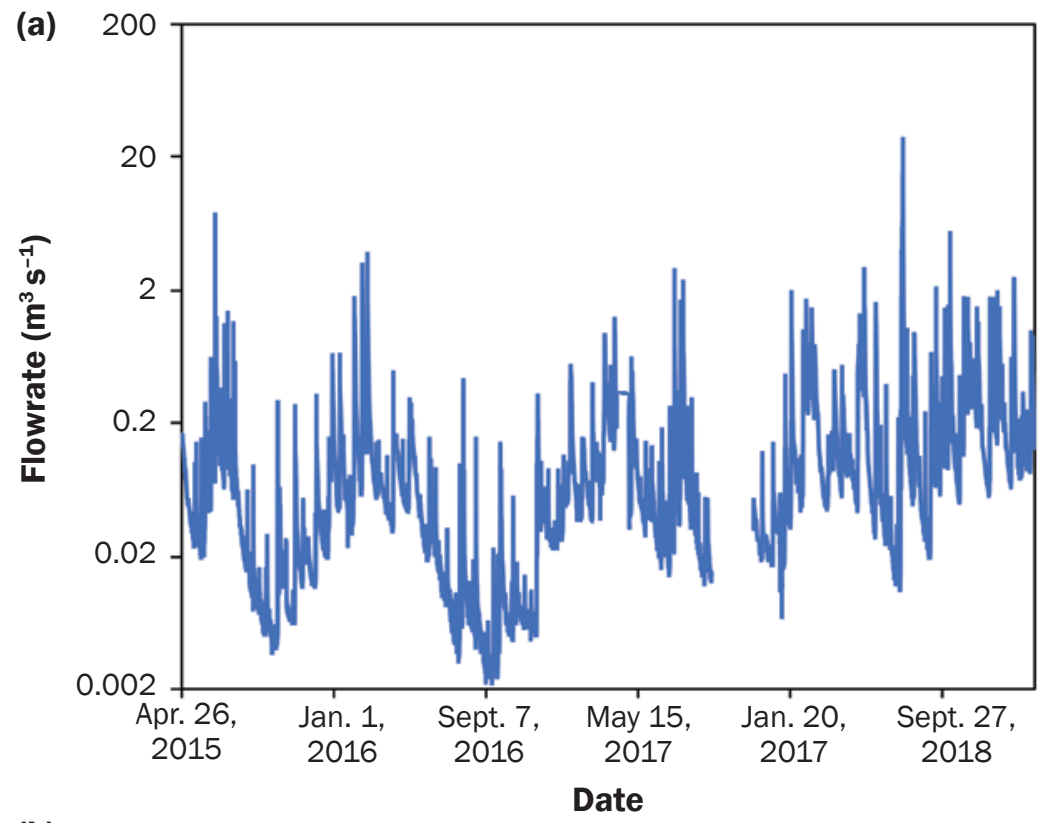

(b)

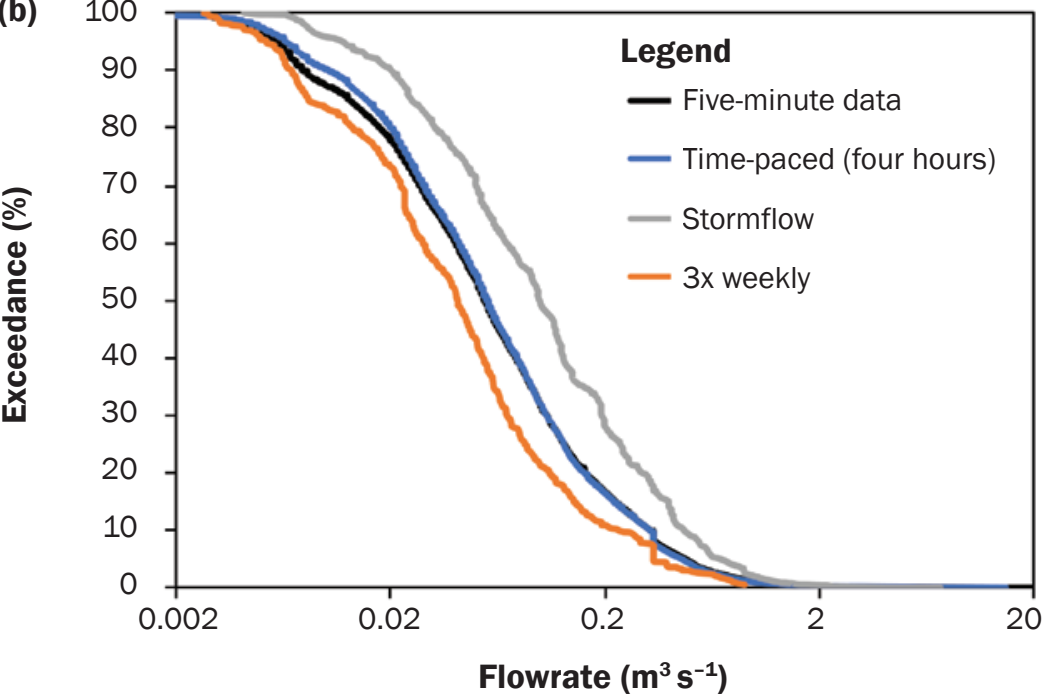

ent above the LOQ. The mobilization of $\mathrm{Al}$ and $\mathrm{Fe}$ in the landscape was likely episodic, as the $C-Q$ relationships showed that the high concentrations of both $\mathrm{Al}$ and $\mathrm{Fe}$ were associated with high flow conditions (figure 4). Therefore, $\mathrm{Al}$ and $\mathrm{Fe}$ appeared to be dominantly transported during surface runoff events, although the source of these constituents to be mobilized with surface runoff was unclear. It is unlikely that $\mathrm{Al}$ and $\mathrm{Fe}$ were present in the parent only during large storm events (Schnabel et al. 1993; Buda et al. 2009; Buda 2013).

$\mathrm{CV}_{\mathrm{C}} / \mathrm{CV}_{\mathrm{Q}}$ ratios (table 2) indicated that nearly all of the constituents of interest can be classified as exhibiting "chemostatic" conditions with nearly constant concentrations throughout the study period, as the ratios for nearly all of the constituents except $\mathrm{PO}_{4}-\mathrm{P}$ and $\mathrm{Al}$ were less than 0.30 (Thompson et al. 2011). For the constituents with low frequency of detection, we note that low $\mathrm{CVC}_{\mathrm{C}}$ $\mathrm{CV}_{\mathrm{Q}}$ ratios do not imply chemostatic conditions as their infrequent detection causes transport dynamics to be episodic.Variability in flow was much greater than concentration variability for the majority of the constituents analyzed, suggesting that hydrologic variability overwhelmingly dominates their transport dynamics from the watershed. The low $\mathrm{CV}_{\mathrm{C}} / \mathrm{CV}_{\mathrm{Q}}$ ratio for $\mathrm{NO}_{3}-\mathrm{N}$ was consistent with results from other dominantly agricultural watersheds (Basu et al. 2010; Guan et al. 2011; Thompson et al. 2011; Gall et al. 2015; Zhang 2018), and suggests that legacy $\mathrm{N}$ sources may have built up in the landscape over decades of agricultural activities within this watershed. This is further supported by a change in the $C-Q$ relationship for $\mathrm{NO}_{3}-\mathrm{N}$, which used to exhibit a positive relationship between flow and discharge several decades ago (1984 to 1987), but now shows much less variability across flow rates, suggesting that groundwater concentrations have increased over the past 30 years of continued agricultural activities in the watershed (Schnabel et al. 1993).

Inequality in Exported Loads. Lorenz curves (figure 5) and corresponding $G_{L}$ values (table 2) further confirmed that for nearly all of the constituents of interest, flow variability was the dominant driver of the loads observed, with the temporal inequality of flow and most of the constituent loads nearly equal $\left(G_{L} / G_{Q} \sim 1\right.$; table 2$)$. Consistent with the other metrics employed, GL/GQ ratios were higher for $\mathrm{NO}_{2}-\mathrm{N}, \mathrm{PO}_{4}-\mathrm{P}, \mathrm{Al}$, and $\mathrm{Fe}$, indicating that the temporal inequality of loads for these constituents was higher than the temporal inequality of the flow.

Examining the temporal manner in which loads were cumulatively discharged from the watershed outlet (figure 6) provided insight into the "hot moments" that were most responsible for each of the constituents of interest. The patterns of cumulative load exported for $\mathrm{NO}_{3}-\mathrm{N}, \mathrm{Cl}$, and $\mathrm{SO}_{4}-\mathrm{S}$ most closely tracked the cumulative export of flow, 


\section{Figure 3}

Boxplot by season for each constituent of interest. Concentrations represent values from the combined data set of all samples. Note: $y$-axis scales differ by constituent.

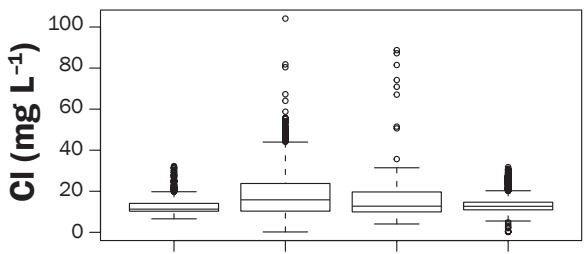

Oct. to Dec. Jan. to Mar. Apr. to June July to Sept.
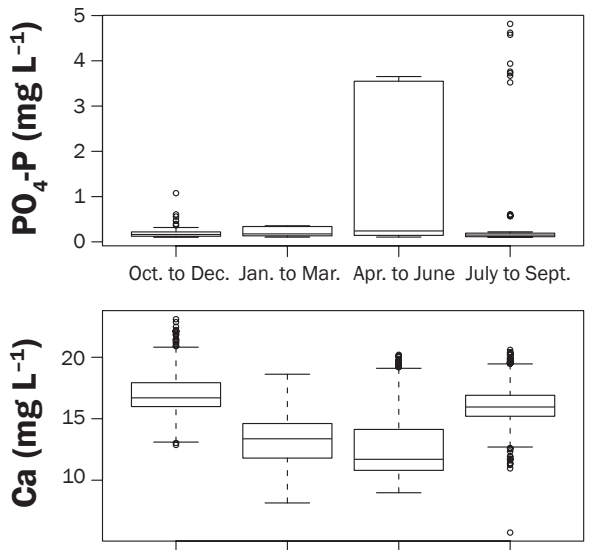

Oct. to Dec. Jan. to Mar. Apr. to June July to Sept.

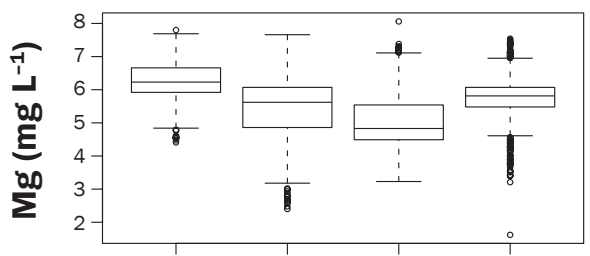

Oct. to Dec. Jan. to Mar. Apr. to June July to Sept.

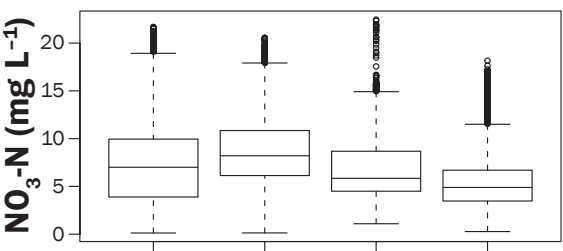

Oct. to Dec. Jan. to Mar. Apr. to June July to Sept.

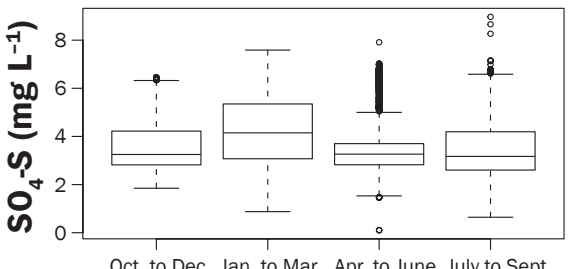

Oct. to Dec. Jan. to Mar. Apr. to June July to Sept.

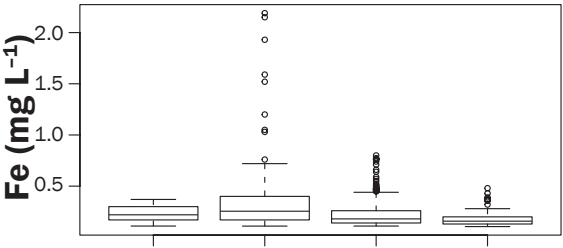

Oct. to Dec. Jan. to Mar. Apr. to June July to Sept.

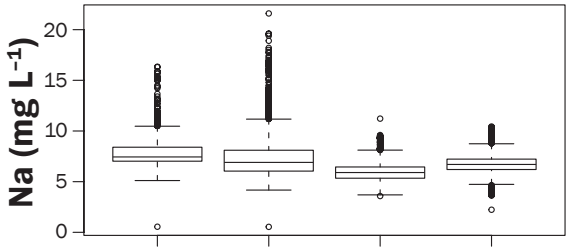

Oct. to Dec. Jan. to Mar. Apr. to June July to Sept.

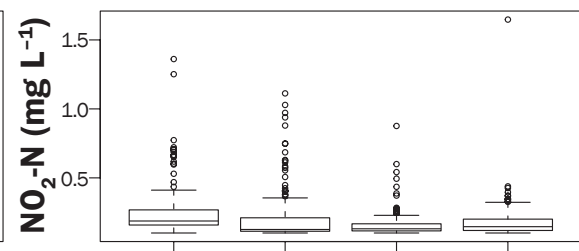

Oct. to Dec. Jan. to Mar. Apr. to June July to Sept.

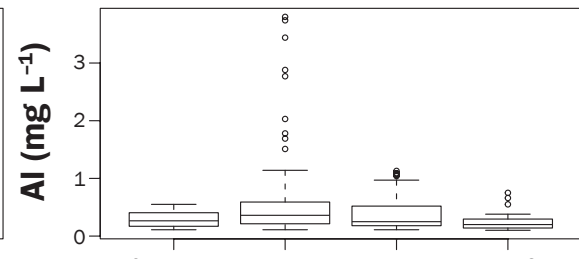

Oct. to Dec. Jan. to Mar. Apr. to June July to Sept.
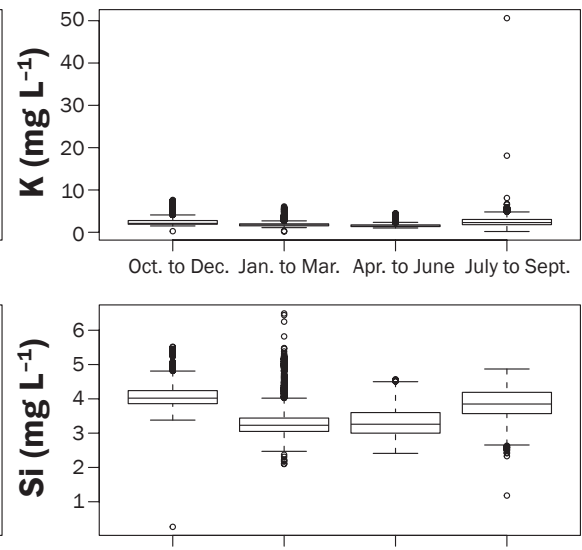

Oct. to Dec. Jan. to Mar. Apr. to June July to Sept. which is consistent with the $G_{L} / G_{Q}$ ratios all being close to 1.0, meaning that the temporal inequality in flow and loads for those constituents were nearly equal. In contrast, the highest $\mathrm{PO}_{4}-\mathrm{P}$ concentrations were observed from June 20 to July 10, 2018, during which $\sim 40 \%$ of the $\mathrm{PO}_{4}-\mathrm{P}$ load observed over the entire study period was mobilized. May of 2018 had been extremely wet in the northeastern part of the United States, and a break in the record high rainfall events occurred early in June. This was likely the earliest farmers could get onto their fields to spread manure, and therefore the high concentrations observed later in the month were likely due to recent manure applications. The greatest load exported for $\mathrm{NO}_{2}-\mathrm{N}$ ( $30 \%$ of the load exported during the study period) was during a two-week period in January of 2018 that likely consisted of a rain-on-snow melting event. Aluminum and $\mathrm{Fe}$ also exhibited several "hot moments" in winter and spring months, such that short periods of time in
December of 2015, 2017, and February of 2018 each contributed to $\sim 10 \%$ of the total loads for the entire study period (figure 6). The emergence of these hot moments for $\mathrm{Al}$, $\mathrm{Fe}, \mathrm{NO}_{2}-\mathrm{N}$, and $\mathrm{PO}_{4}-\mathrm{P}$ were consistent with the episodic transport dynamics identified with the $b$ and $\mathrm{CV}_{\mathrm{C}} / \mathrm{CV}_{\mathrm{Q}}$ metrics (table 2).

Despite a significant agricultural presence in the watershed $(55 \%$ of the land use), $\mathrm{PO}_{4}-\mathrm{P}$ does not exhibit chemostatic conditions, suggesting that the long-term agricultural activities in this watershed (since pre-1960s) have not overwhelmed the landscape's natural ability to serve as an effective biogeochemical filter for $\mathrm{PO}_{4}-\mathrm{P}$. These results are in contrast to the chemostatic conditions that have been documented extensively for both $\mathrm{N}$ and $\mathrm{P}$ in intensively managed agricultural watersheds worldwide (Basu et al.2010; Guan et al.2011; Thompson et al. 2011; Haygarth et al. 2014; Gall et al. 2015; Dodd and Sharpley 2016; Miller et al. 2019). Significant efforts have been made by Northumberland County Conservation District and farmers within the watershed to adopt best management and conservation practices such as conservation tillage, contour cropping, fall manure application, and riparian buffers. Each of these best management practices has been adopted specifically to reduce sediment and $\mathrm{P}$ losses, lending evidence to suggest that best management practices aimed to reduce $\mathrm{P}$ accumulation in the watershed over the past $20+$ years have been largely successful.

\section{Summary and Conclusions}

More than 12,500 water samples analyzed for 12 constituents of natural and anthropogenic origin were collected with three sampling strategies and examined over a four-year period to characterize the transport dynamics of each constituent. Of the three sampling strategies-(1) three times weekly; (2) stormflow (triggered every half hour during storm events); and (3) time-paced (every four 


\section{Figure 4}

Concentration-discharge (C-Q) relationships for each constituent of interest for each of the sampling strategies: (1) three times per week, (2) stormflow sampling, and (3) time-paced sampling (every four hours). Please note that the number of samples with concentrations above the method limit of quantification is less than $10 \%$ for nitrite-nitrogen $\left(\mathrm{NO}_{2}-\mathrm{N}\right)$ and less than $2 \%$ for orthophosphate $\left(\mathrm{PO}_{4}-\mathrm{P}\right)$, aluminum ( $\mathrm{Al}$ ), and iron ( $\left.\mathrm{Fe}\right)(\mathrm{see}$ table 1$)$.
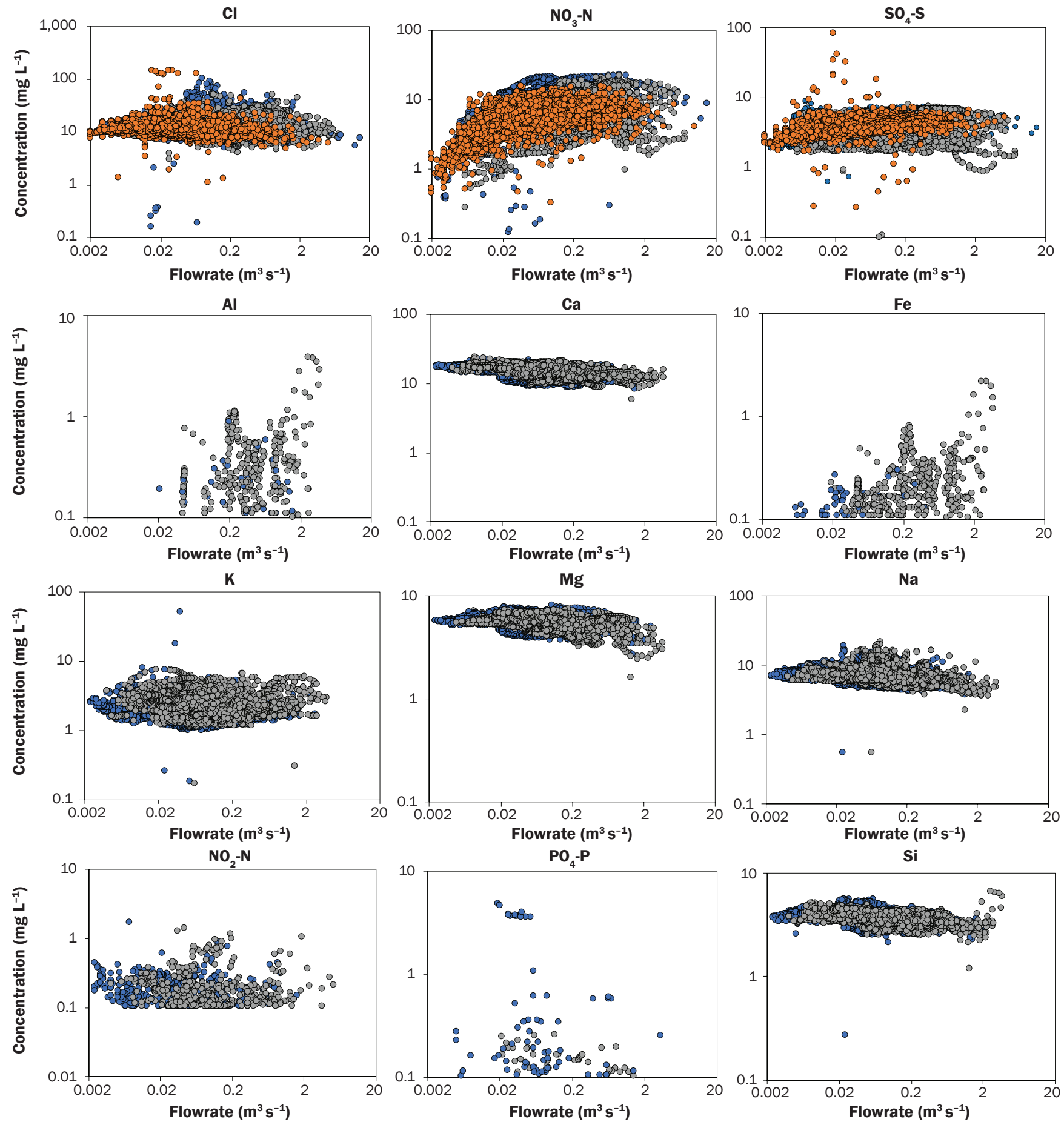

\section{Legend}

- Time-paced (four hours)

- Stormflow

- 3x weekly 


\begin{tabular}{|c|c|c|c|c|}
\hline Constituent & $\boldsymbol{b}$ & $\mathrm{CV} / \mathrm{CVQ}$ & $G_{L}$ & $G_{L} / G_{Q}$ \\
\hline Chloride & 0.06 & 0.15 & 0.65 & 1.00 \\
\hline Nitrate-N & 0.26 & 0.16 & 0.69 & 1.07 \\
\hline Nitrite-N* & -0.05 & 0.32 & 0.97 & 1.51 \\
\hline Ortho-phosphate* & -0.24 & 0.58 & 1.00 & 1.55 \\
\hline Sulfate-S & 0.13 & 0.11 & 0.66 & 1.03 \\
\hline Aluminum* & 0.00 & 0.86 & 1.00 & 1.55 \\
\hline Calcium & -0.09 & 0.12 & 0.73 & 1.13 \\
\hline Iron* & 0.10 & 0.35 & 1.00 & 1.55 \\
\hline Potassium & -0.07 & 0.34 & 0.75 & 1.17 \\
\hline Magnesium & -0.04 & 0.10 & 0.74 & 1.14 \\
\hline Sodium & -0.07 & 0.14 & 0.73 & 1.13 \\
\hline Silica & -0.06 & 0.10 & 0.73 & 1.13 \\
\hline
\end{tabular}

Notes: $\mathrm{N}=$ nitrogen. $\mathrm{S}=$ sulfur.

*For these constituents, $<10 \%$ of the samples had concentrations above the LOQ (see table 1 ).

hours) - the time-paced sampling resulted in $\sim 7,000$ water samples and captured the full range of flowrates observed during the study period. $C-\mathrm{Q}$ relationships, $\mathrm{CV} / \mathrm{CV}_{\mathrm{Q}}$ ratios, and $G_{L} / G_{Q}$ ratios were employed to classify each constituent as exhibiting chemostatic, accretion, or dilution transport patterns.

Overall, the majority of the geogenic constituents of interest $(\mathrm{Ca}, \mathrm{Cl}, \mathrm{Mg}, \mathrm{Na}$, and Si) exhibited chemostatic transport behavior, with low variability in concentrations observed over the entire range of flows. Nitrate-N, $\mathrm{SO}_{4}-\mathrm{S}$, and $\mathrm{K}$ also exhibited chemostatic dynamics with low concentration variability and high frequencies of detection, suggesting that anthropogenic inputs from fertilizer and manure $\left(\mathrm{NO}_{3}-\mathrm{N}\right.$ and $\left.\mathrm{K}\right)$ and from industry $\left(\mathrm{SO}_{4}-\mathrm{S}\right)$ have led to the emergence of legacy sources within the watershed that are enabling their transport to be chemostatic. Of particular interest is that $\mathrm{PO}_{4}-\mathrm{P}$ was present at detectable concentrations at the watershed outlet in a low percentage $(<20 \%)$ of the samples collected and exhibited strong episodic transport dynamics as evidenced by high $\mathrm{CV}_{C} / \mathrm{CV}_{\mathrm{Q}}$ and $\mathrm{GL}_{L} / \mathrm{GQ}_{\mathrm{Q}}$ ratios.

These results suggest that agricultural activities have led to the emergence of $\mathrm{N}$ but not $\mathrm{P}$ legacy sources within the watershed. Future adoption of best management practices is likely to continue to keep the watershed within its biogeochemical limits, with the watershed retaining its ability to act as an effective biogeochemical filter for P. However, a temporal lag in $\mathrm{N}$ load reduction is likely to be observed given the extent of the $\mathrm{N}$ legacy sources already accumulated within the landscape. The results of the temporal inequality analysis suggest that $\mathrm{NO}_{3}-\mathrm{N}$ exhibits a moderate degree of temporal inequality, with a $G L$ value of $\sim 0.7$. To achieve load reduction goals consistent with those required by the Chesapeake Bay total maximum daily load ( $25 \%)$, either low flow or high flow could be targeted with appropriate best management practices. To effectively treat low flow to achieve a $25 \%$ load reduction, the lowest $55 \%$ of the observed flowrates would need to be targeted. Conversely, a $25 \%$ load reduction goal could also be achieved by mitigating loads during the top $5 \%$ of the flowrates. Continued adoption of best management practices not specifically designed to treat either long durations of low flow or short periods of high flow events may not reduce $\mathrm{NO}_{3}-\mathrm{N}$ loads below current observed levels.

\section{Acknowledgements}

The quantity and quality of these data are due to the unwavering technical support and troubleshooting of the Agricultural Research Service-Pasture Systems and Watershed Management Research Unit (ARS-PSWMRU) Klingerstown crew, who maintain the weirs and sampling equipment and collect the data, and to the chemists in the ARS-PSWMRU water analysis lab. Heather E. Preisendanz is supported, in part, by the Pennsylvania State University Institutes of Energy and the Environment and the USDA National Institute of Food and Agriculture Federal Appropriations under Project PEN04574 and Accession number 1004448. This research and assessment was supported by the USDA Natural Resources Conservation Service Conservation Effects Assessment Project Watershed Assessment Studies and Agricultural Research Service National Program 211.

\section{Disclaimer}

The findings and conclusions in this publication are those of the author(s) and should not be construed to represent any official USDA determination or policy. Mention of trade names or commercial products in this publication is solely for the purpose of providing specific information and does not imply recommendation or endorsement by The Pennsylvania State University or the USDA. All entities involved are equal opportunity providers and employers.

\section{References}

Basu, N.B., G. Destouni, J.W. Jawitz, S.E. Thompson, N.V. Loukinova, A. Darracq, S. Zanardo, M. Yaeger, M. Sivapalan, A. Rinaldo, and P.S.C. Rao. 2010. Nutrient loads exported from managed catchments reveal emergent biogeochemical stationarity. Geophysical Research Letters 37:L23404.

Basu, N.B., S.E.Thompson, and P.S.C. Rao. 2011. Hydrologic and biogeochemical functioning of intensively managed catchments: A synthesis of top-down analyses. Water Resources Research 47:W00J15.

Bryant, R.B., T.L. Veith, G.W. Feyereisen, A.R. Buda, C.D. Church, G.J. Folmar, J.P. Schmidt, C.J. Dell, and P.J.A. Kleinman. 2011. USDA-ARS Mahantango Creek watershed, Pennsylvania, United States: Physiography and history. Water Resources Research 47: W08701, doi:10.1029/2010WR010056.

Buda, A. 2013. Surface-runoff generation and forms of overland flow. In Treatise on Geomorphology, Volume 7, 73-84. Amsterdam: Elsevier Inc. https://doi. org/10.1016/B978-0-12-374739-6.00151-2.

Buda, A.R., G.W. Feyereisen, T.L. Veith, G.J. Folmar, R.B. Bryant, C.D. Church, J.P. Schmidt, J.P., C.J. Dell, and P.J.A. Kleinman. 2011. USDA-ARS Mahantango Creek watershed, Pennsylvania, United States: Long-term stream discharge database. Water Resources Research 47:W08703, doi:10.1029/2010WR010059.

Buda, A.R., P.J. Kleinman, M.S. Srinivasan, R.B. Bryant, and G.W. Feyereisen. 2009. Factors influencing surface runoff generation from two agricultural hillslopes in central Pennsylvania. Hydrologic Processes 23:12951312, doi:10.1002/hyp.7237.

Church, C.D., T.L. Veith, G.F. Folmar, A.R. Buda, G.W Feyereisen, R.B. Bryant, J.P. Schmidt, C.J. Dell, and P.J.A. Kleinman. 2011. USDA-ARS Mahantango Creek watershed, Pennsylvania, United States: Longterm water quality database. Water Resources Research W08704, doi:10.1029/2010WR010060.

Dodd, R.J., and A.N. Sharpley. 2016. Conservation practice effectiveness and adoption: Unintended consequences and implications for sustainable phosphorus 
Figure 5

Lorenz inequality curves for discharge and each of the constituents of interest for samples collected for the time-paced sampling strategy (every four hours). The further away from the 1:1 line that the Lorenz curves fall, the greater the temporal inequality of the constituent transport. When the constituent Lorenz curves overlap the discharge Lorenz curve, the transport dynamics are considered to be chemostatic (Group 1). Episodic transport occurs when high portions of load are exported during small portions of time (Group 3).

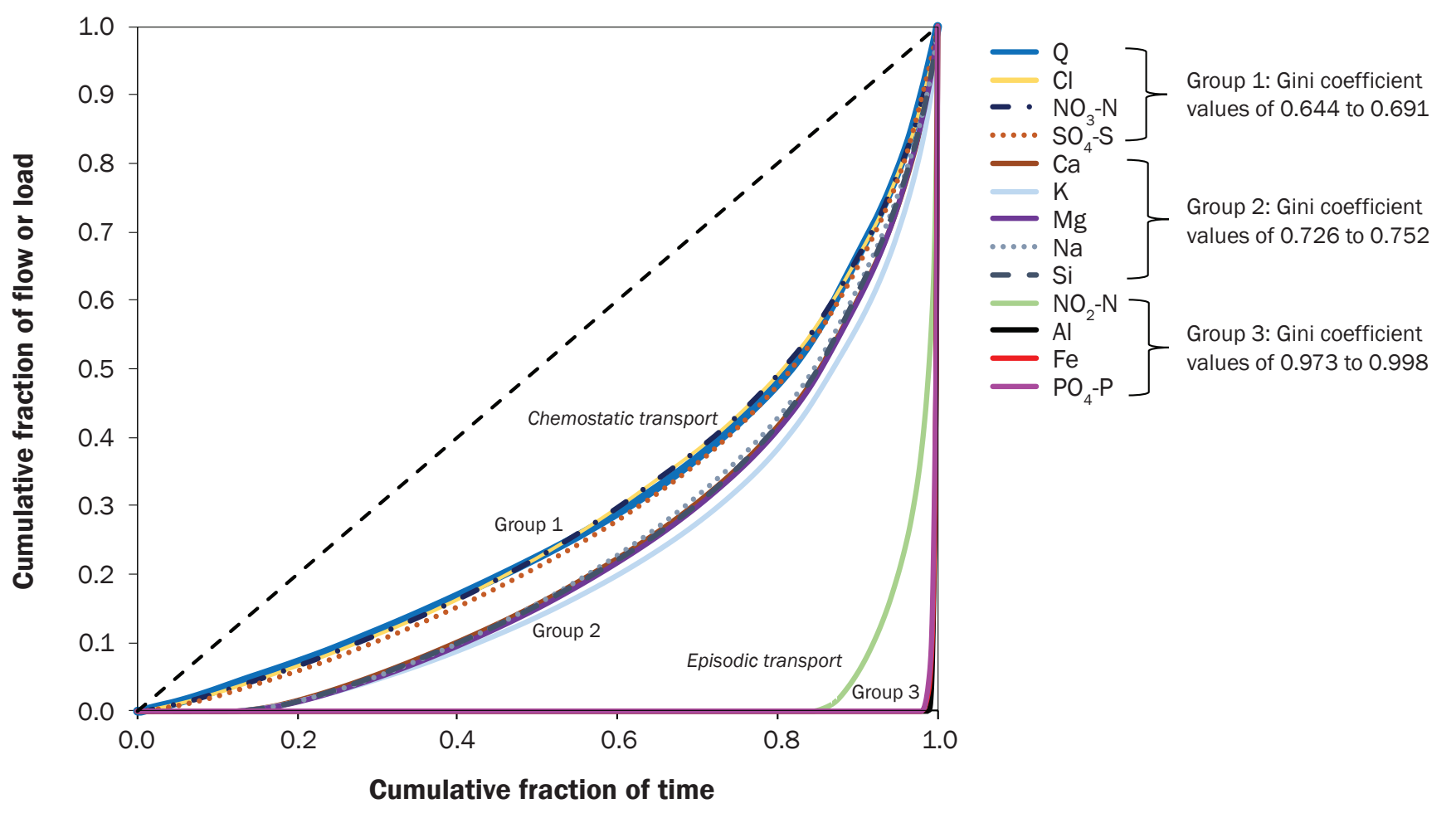

management. Nutrient Cycling in Agroecosystems 104:373-392.

Duffy, C.J., and J. Cusumano. 1998. A low dimensional model for concentration-discharge dynamics in groundwater stream systems. Water Resources Research 34:2235-2247.

Elkin, K.R., T.L. Veith, H. Lu, S.C. Goslee, A.R. Buda, A.S. Collick, G.J. Folmar, P.J.A. Kleinman, and R.B. Bryant. 2016. Declining atmospheric sulfate deposition in an agricultural watershed in central Pennsylvania, USA. Agricultural and Environmental Letters 1:160039, doi:10.2134/ael2016.09.0039.

Gall, H.E. C.T. Jafvert, and B. Jenkinson. 2010. Integrating hydrograph modeling with real-time monitoring to generate hydrograph-specific sampling schemes. Journal of Hydrology 393:331-340.

Gall, H.E., J. Park, C.J. Harman, J.W. Jawitz, and P.S.C. Rao. 2013. Landscape filtering of hydrologic and biogeochemical responses in managed catchments. Landscape Ecology 28:651-664.

Gall, H.E., S.A. Sassman, B. Jenkinson, L.S. Lee, and C.T. Jafvert. 2015. Comparison of export dynamics of nutrients and animal-borne estrogens from a tiedrained Midwestern agroecosystem. Water Research 72:162-173.

Gburek,W.J., and G.J. Folmar. 1999. A groundwater recharge field study: Site characterization and initial results.
Hydrologic Processes 13:2813-2831, doi:10.1002/ (SICI) 1099-1085(19991215)13:17<2813::AIDHYP901>3.0.CO;2-6.

Godsey, S.E., J.W. Kirchner, and D.W. Clow. 2009. Concentration-discharge relationships reflect chemostatic characteristics of US catchments. Hydrological Processes 23:1844-1864.

Guan, K., S.E. Thompson, C.J. Harman, N.B. Basu, P.S.C. Rao, M. Sivapalan, A.I. Packman, and P.K. Kalita. 2011. Spatiotemporal scaling of hydrological and agrochemical export dynamics in a tile-drained midwestern watershed. Water Resources Research 47:W00J02.

Haggard, B.E., T.S. Soerens, W.R. Green, and R.P. Richards. 2003. Using regression methods to estimate stream phosphorus loads at the Illinois River, Arkansas. Applied Engineering in Agriculture 19:187-194.

Halliday, S.J., A.J. Wade, R.A. Skeffington, C. Neal, B. Reynolds, P. Rowland, M. Neal, and D. Norris. 2012. An analysis of long-term trends, seasonality and shortterm dynamics in water quality from Plynlimon, Wales. Science of the Total Environment 434:186-200.

Harmel, R.D., K.W. King, and R.M. Slade. 2003. Automated storm water sampling on small watersheds. Applied Engineering in Agriculture 19(6):667-674.

Haygarth, P.M., H.P. Jarvie, S.M. Powers, A.N. Sharpley, J.J. Elser, J.B. Shen, H.M. Peterson, N.I. Chan, N.J.K. Howden, T. Burt, F. Worrall, F.S. Zhang, and X.J. Liu.
2014. Sustainable phosphorus management and the need for a long-term perspective: The legacy hypothesis. Environmental Science and Technology 48:8417-8419.

Haygarth, P., B.L. Turner, A. Fraser, S. Jarvis, T. Harrod, D. Nash, D. Halliwell, T. Page, and K. Beven. 2004. Temporal variability in phosphorus transfers: Classifying concentration-discharge event dynamics. Hydrology and Earth Systems Science 8:88-97.

Jawitz, J.W., and M. Mitchell. 2011. Temporal inequality in catchment discharge and solute export. Water Resources Research 47:W00J14.

Johnson, N.B., G.E. Likens, F.H. Bormann, D.W. Fisher, and R.S. Pierce. 1969. A working model for the variation in stream water chemistry at the Hubbard Brook Experimental Forest, New Hampshire. Water Resources Research 5:1353-1363.

King, K.W., and R.D. Harmel. 2004. Comparison of time-based sampling strategies to determine nitrogen loading in plot-scale runoff. Transactions of the ASABE 47(5):1457-1463.

King, K.W., R.D. Harmel, and N.R. Fausey. 2005. Development and sensitivity of a method to select time- and flow-paced storm event sampling intervals for headwater streams. Journal of Soil and Water Conservation 60(6):323-331.

Liu, J., T.L. Veith, A.S. Collick, P.J.A. Kleinman, D.B. Beegle, and R.B. Bryant. 2017. Seasonal manure application 


\section{Figure 6}

Cumulative loads exported over the study period for each of the constituents of interest. Note that samples with concentrations below the limit of detection (LOD) were not considered to contribute to the loads. Loads were calculated from the time-paced samples collected every four hours.

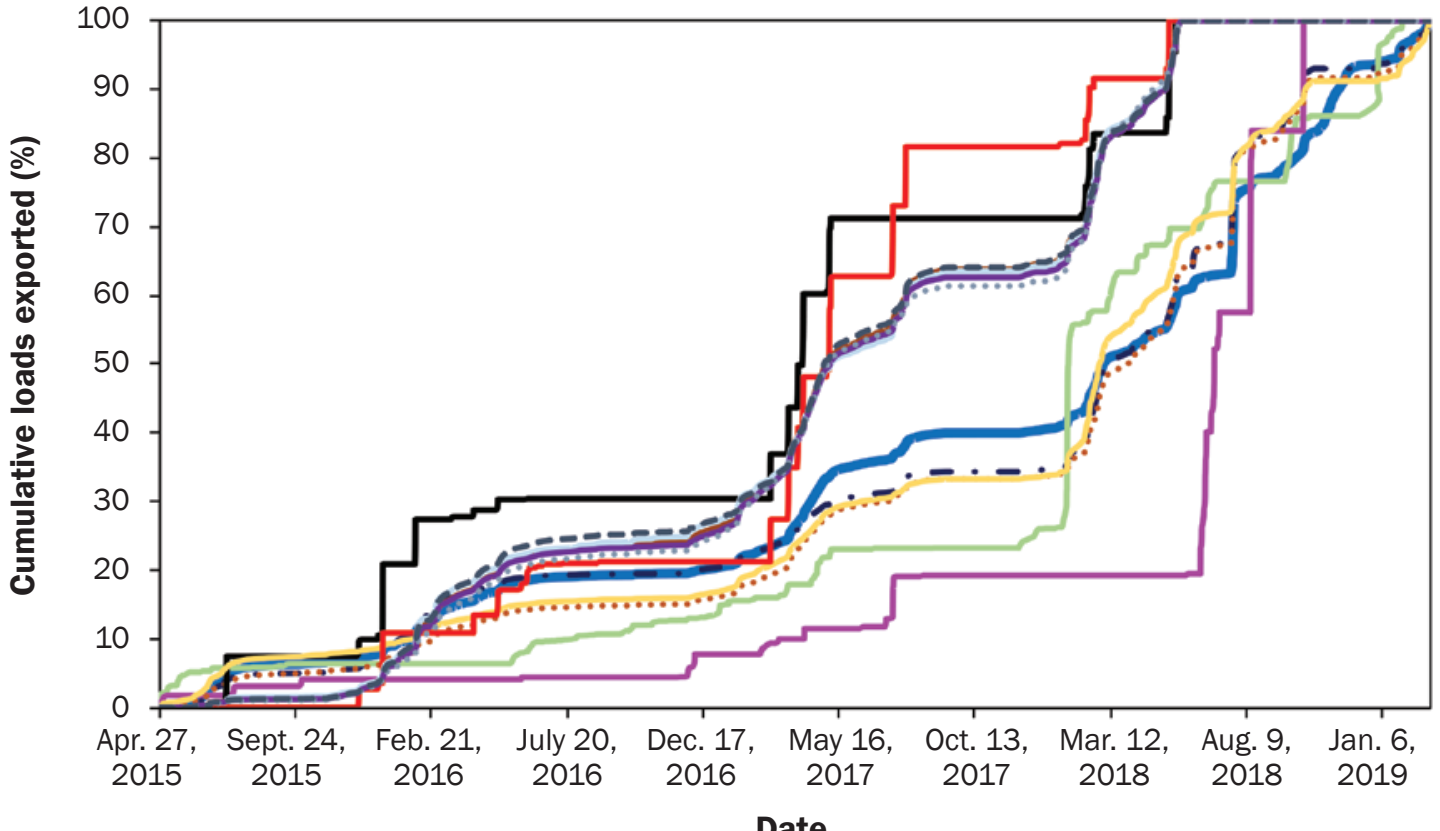

Legend

Date

$\begin{array}{lll}-\mathrm{Al} & -\mathrm{Mg} \\ -\mathrm{Ca} \mathrm{NO}_{3}-\mathrm{N} & -\cdots \mathrm{Na} \\ \mathrm{NO}_{2}-\mathrm{N} & -\mathrm{Cl} & -\cdots \mathrm{Si} \\ -\mathrm{PO}_{4}-\mathrm{P} & -\mathrm{Fe} & \\ \cdots \mathrm{SO}_{4}-\mathrm{S} & -\mathrm{K} & \end{array}$

timing and storage effects on field- and watershed-level phosphorus losses. Journal of Environmental Quality 46:1403-1412.

Mańczak, H., and H. Florczyk. 1971. Interpretation of results from the studies of pollution of surface flowing waters. Water Research 5:575-584.

Masaki, Y., N. Hanasaki, K. Takahashi, and Y. Hijioka. 2014 Global-scale analysis on future changes in flow regimes using Gini and Lorenz asymmetry coefficients. Water Resources Research 50:4054-4078.

Miller, M.D., H.E. Gall, A.R. Buda, L.S. Saporito, T.L.Veith, C.M. White, C.F. Williams, K.J. Brasier, P.J.A. Kleinman, and J.E. Watson. 2019. Load-discharge relationships reveal the efficacy of manure application practices on phosphorus and total solids losses from agricultural fields. Agriculture, Ecosystems and Environment 272:19-28.

Musolff, A., C. Schmidt, B. Selle, and J.H. Fleckenstein. 2015.

Catchment controls on solute export. Advances in Water Resources 86:133-146.

NOAA (National Oceanic and Atmospheric Administration) National Centers for Environmental Information. 2019. National temperature and precipitation maps. Silver Spring, MD: National Oceanic and Atmospheric Administration. https://www.ncdc.noaa.gov/temp-and-precip/us-maps/.

Opalinski, N., D. Schultz, H.E. Gall, and M. Royer. 2016. Development of a decision-making framework for BMP design to reduce loads during "hot moments". ASABE
Paper No. 2456929. St. Joseph, MI:American Society of Agricultural and Biological Engineers.

Robertson, D., and E. Roerish. 1999. Influence of various water quality sampling strategies on load estimates for small streams. Water Resources Research 35:3747-3759.

Schnabel,R.R.,J.B.Urban, andW.J. Gburek.1993.Hydrologic controls in nitrate, sulfate, and chloride concentrations. Journal of Environmental Quality 22:589-596, doi:10.2134/jeq1993.00472425002200030025x.

Swistock, B. 2015. Interpreting drinking water tests for dairy cows. University Park, PA PennState Extension. https://extension.psu.edu/ interpreting-drinking-water-tests-for-dairy-cows.

Thompson, S.E., N.B. Basu, J. Lascurain Jr., A. Aubeneau, and P.S.C. Rao. 2011. Relative dominance of hydrologic versus biogeochemical factors on solute export across impact gradients. Water Resources Research 47:W00J05

Ullrich, A., and M. Volk. 2010. Influence of different nitrate- $\mathrm{N}$ monitoring strategies on load estimation as a base for model calibration and validation. Environmental Monitoring and Assessment 171:513-527.

USDA ARS (Agricultural Research Service). 2019 The Long-Term Agroecosystem Research (LTAR) Network. Washington, DC: USDA Agricultural Research Service. https://www.ars.usda.gov/naturalresources-and-sustainable-agricultural-systems water-availability-and-watershed-management/docs/ long-term-agroecosystem-research-ltar-network/ .

USDA NRCS (Natural Resources Conservation Service. 2019. Conservation Effects Assessment Project (CEAP). Washington, DC: USDA Natural Resources Conservation Service. https://www.nrcs.usda.gov/wps/ portal/nrcs/main/national/technical/nra/ceap/.

USEPA (US Environmental Protection Agency). 2019 National primary drinking water regulations.Washington, DC: US Environmental Protection Agency. https:// www.epa.gov/ground-water-and-drinking-water/ national-primary-drinking-water-regulations.

Veith, T.L., J.E. Richards, S.C. Goslee, A.S. Collick, R.B Bryant, D.A. Miller, B. Bills, A.R. Buda, R.L. Sebring, and P.J.A. Kleinman. 2015. Navigating spatial and temporal complexity in developing a long-term land use database for an agricultural watershed. Journal of Soil and Water Conservation 70(5):288-296, doi:10.2489/ jswc.70.5.288.

Vogel, R.M., B.E. Rudolph, and R.P. Hooper. 2005. Probabilistic behavior of water-quality loads. Journal of Environmental Engineering 131:1081-1089.

Zhang, Q. 2018. Synthesis of nutrient and sediment export patterns in the Chesapeake Bay watershed: Complex and non-stationary concentration-discharge relationships. Science of the Total Environment 618:1268-1283, doi:10.1016/j.scitotenv.2017.09.221. 